\title{
Governing the Canadian State: The Constitution in an Era of Globalization, Neo-Liberalism, Populism, Decentralization and Judicial Activism
}

Harry W. Arthurs

Osgoode Hall Law School of York University, harthurs@osgoode.yorku.ca

Follow this and additional works at: http://digitalcommons.osgoode.yorku.ca/scholarly_works

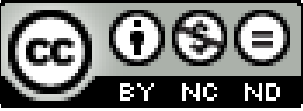

This work is licensed under a Creative Commons Attribution-Noncommercial-No Derivative Works 4.0 License.

\section{Recommended Citation}

Arthurs, Harry W. "Governing the Canadian State: The Constitution in an Era of Globalization, Neo-Liberalism, Populism, Decentralization and Judicial Activism." Constitutional Forum 13.1 (2003): 16-24. 


\title{
Governing the Canadian State: The Constitution in aN ERa of Globalization, Neo-Liberalism, POPULISM, DECENTRALIZATION AND JUdICIAL ACTIVISM
}

\author{
Harry W. Arthurs
}

\section{INTRODUCTION: A DONKEY'S PERSPECTIVE ON THE CONSTITUTION}

Viewer discretion is advised. I am going to offer you a perspective on the constitution which is stranger even than the Trudeau vision which twenty years ago sparked his epic battles with Merv Leitch and Peter Lougheed over the National Energy Policy, the Charter,' and repatriation of the Constitution. And worse yet, though I worry about the Constitution, I do not know much about it; I do not often write about it, and as I will demonstrate in a moment, I am not even sure what it is. I did, however, read something recently in a book on modern European history which seemed to capture my own sentiments almost exactly - an observation attributed to a peasant in Salonika, then under Turkish rule, in 1908: "Constitution is such a wonderful thing," said this peasant, "that he who does not know what it is, is a donkey." I identify with the donkey, not the peasant.

This puts me at a serious disadvantage in today's world. Scores of post-colonial and post-communist societies are attempting to turn the page of history by drafting new and more perfect fundamental laws. Established democracies are attempting to solve their

\footnotetext{
Canadian Charter of Rights and Freedoms, Part 1 of the Constitution Act, 1982, being Schedule B to the Canada Act 1982 (U.K.), 1982, c. 11 [Charler]

2 M. Mazower The Dark Continent: Europe 's Twentieth Century (New York: Vintage Books, 2000) at 6. Mazower does not cite his sonrce.

3 My identity arguably puts me on the side of the angels. As recounted in Numbers 22:21 et seq, a donkey was three times beaten by his master, the prophet Balaam, for refusing to carry him on a mission on behalf of the princes of Moab to curse the children of Israel. In fact, the donkey had balked in order to save Balaam from the wrath of an armed angel - invisible to Balaam, but visible to the donkey - who had been dispatched to forestall the Moabite persecution. I am grateful to $\mathrm{T}_{\mathrm{sv}}$ Kahana for drawing this som etimes overlooked biblical episode to my attention, thereby diminishing my embarrassment at
} labelling myself a donkey. complex political, social and economic problems by reinterpreting or rewriting their constitutions. And here in Canada, especially in academic circles and in the appellate courts, constitutional concerns and Charter chatter dominate the agenda though, I suspect, Canadian peasants do not show quite the same enthusiasm for constitutions as did that rustic sage of Salonika. So here I am, playing donkey: what exactly is a constitution?

I start with a simple notion. Constitutions constitute. They define or redefine states, sub-state entities, their institutions, and the relationship amongst all of the above. They set out the rights and duties of citizens and articulate the values, aspirations and understandings by which ethnic, class, gender, cultural, regional, religious, linguistic and other groups associate within the state. They prescribe a framework within which state law, administration and policies must be conducted. Finally, constitutions are iconic symbols of continuity or discontinuity with the past, of legitimacy for the present, of prom ise for the future. Constitutions constitute.

However there is a difficulty. Constitutions - at least in the lawyer's sense of the term - constitute less in practice than in theory. Some states with written constitutions utterly transform themselves over time with few, if any, formal constitutional amendments and sometimes even without recourse to judicial review. Others adopt one constitutional amendment after another and nothing changes. Similarly, while some states without written constitutions adapt easily to changing ideas of what is fundamental, indispensable or appropriate in their juridical and political arrangements, others do not.

So constitutions count for something: but not that much. True, states do need a foundation of fundamental norms. But such a foundation does not have to be the formal, juridical "constitution." It may consist of many other things: the deep structures and conventions of 
political life; long-standing compacts amongst "founding peoples," religious communities or geographic regions; the conventional wisdom and habitual practices of mandarin classes, judges, corporate elites and knowledge communities; the tutelary influence of imperial or transnational institutions; or some vague sense amongst citizens of shared experience, interests and values. In practical terms, any of these - or the end of any of these - can reinforce, modify or displace the practical, the juridical, even the symbolic, functions of a "constitution." These are odd ideas about a constitution; I will acknowledge that. However, since donkeys are not only stupid but stubborn, I am going to stick with them.

\section{THE CONSTITUTIONALIZATION OF POLITICS}

As indicated in the title of this paper, I believe that our Constitution - in the expanded sense that I have just described - is being reshaped by five powerful forces: neo-liberalism, globalization, populism, decentralization and judicial activism. Our institutions are changing; our values are changing; the way we talk and think about things is changing. Moreover, the changes $I$ describe are not just part of the normal evolution of institutions, values and political discourse that takes place in any healthy society. They are constitutional in character. Whether that is our intention or not, we are making it much more difficult to reverse present tendencies, to return to old values, institutions and discourses, or to adopt new ones at some point in the future. Our new constitution, I maintain, is being chiselled in stone. Now many people will argue that this is a good thing, that this is exactly what constitutions are supposed to do, and that Canada is facing such serious challenges that it has to reinvent itself. I agree; we do face serious challenges; we have to reinvent ourselves.

Here is one list of what many Canadians would identify as our greatest challenges: How can we free up the energy and imagination of Canadians so that we can regain our status as one of the world's most productive and affluent nations? How can we ensure that our economy is not strangled by government regulation, that our entrepreneurs and brightest minds are not driven abroad by excessive taxation, that our young people do not succumb to habits of dependency and self indulgence? How can we ensure that power is exercised by governments which are close to the people, rather than by remote bureaucrats in Ottawa? How can we make all public institutions more accountable, more responsive to the opinions and desires of ordinary Canadians? How can we protect the social values and cultural traditions which built this country and which remain our best guide for the future?

That is one version of a list, but there are lots of versions. My own is somewhat different: How can we exercise our sovereignty and preserve our identity in the shadow of the American colossus? How can we succeed in a globalized world without control over key sectors of our own domestic economy, and with our relatively small pool of human and financial capital? How can we accommodate the aspirations of Quebec, of aboriginal nations and of assertive provinces, regions and metropolitan areas within a federation in which the central government is already precluded from addressing key issues which no one else can resolve? How can we interest our citizens in electoral politics and other forms of civic engagement? How can we pay for the public services and infrastructure that we want and need? And what will be left of the Canada we once knew - the state which built our economic infrastructure, which breathed life into our cultural institutions, which provided economic security and social services to Canadians - what will be left of that Canada once we have finished stripping the state of resources, of legitimacy and of any hope or means of recovering these?

Now to ask an obvious question. If our visions of the challenges facing Canada are so very different, how can we as a nation get on and do something about them? I have a short and simple-minded answer to that question: we try to elect the political party which comes closest to our sense of where the country needs to go. of course we can not realistically expect that any government will follow through completely: it wants to stay in power, so it must build some bridges to people who opposed it; it will never have enough resources, so it needs to set priorities and arrange compromises amongst its supporters; it may develop new analyses or confront new circumstances and have to change its policies; it may be unable to deal quickly with some problems because they are structural or others because they are totally beyond its powers. And we have to accept that - being composed of fallible people some governments will simply disappoint us. If they do, however, at some point discontents will accumulate, new ideas and personalities will emerge, public opinion will shift, and a new government will be elected.

This rather boring, highly imperfect - some would say terminally ineffectual - process answers to the name of parliamentary democracy. Some people who are frustrated by it - and I am not one of them favour radical solutions, all of them arguably democratic though not necessarily parliamentary. These solutions come down to an attempt to permanently change the rules of Canadian politics. Its advocates 
hope that by some process - constitutional amendment, judicial intervention, restructuring of the social and economic fabric of the nation, privileging certain communities or values over others - it will be made impossible for people who hold opposing views to ever gain power, or if they do, to implement those views. This strategy of seeking to permanently change the rules of politics and fix forever the future course of government, I am going to refer to as the constitutionalization of politics.

\section{CONSTITUTIONALIZING NEO- LIBERALISM}

The constitutionalization of politics enjoys considerable support on the left, from the so-called Court Party of equality-seeking groups, from progressive lawyers and law professors and from social democrats who only ten years ago promoted a Social Charter as part of the Charlottetown Accord. But these groups are pretty marginal today. Most of the people who want to make their ideas permanent, who want to forever preempt alternative visions, are neo-liberals. They have one primary goal: they want to drive a stake through the heart of the activist state; to "constitutionalize" neo-liberalism; to entrench low taxes, smaller government, unregulated markets and free trade with the United States; and to reallocate powers amongst the various branches and levels of government in such a way as to forever foreclose egalitarian, social democratic, centralizing, nationalist or other deviations. To reiterate an earlier point: little of this requires amendment to our Constitution Act; yet the intended result is meant to be chiselled in juridical stone. I will explain quickly, beginning with taxes, from which much else follows.

Canadians aspire to maintain social services, support our national cultures, and avoid American-style extremes of economic inequality - all of which cost money. However, Canadians have also been persuaded that they are overtaxed, and that our economy will suffer so long as we have higher corporate and personal tax rates than the United States. As a result, many provinces have adopted legislation forbidding governments to raise taxes or run deficits. In Ontario, my own province, new legislation provides that taxes cannot be increased, and new taxes cannot be introduced, without a referendum; if the government budgets for a deficit, cabinet members automatically forfeit a portion of their annual salary. ${ }^{4}$ While perhaps not, in a formal sense, "constitutional," this legislation is for practical purposes unrepealable. This ensures that

Taxpayer Prolection Act. 1999, S.O. 1999, c. 7, Sched. A; Balanced Budget Act, 1999, S.O. 1999, c. 7, Sched. B. all decisions hereafter are zero-sum decisions. If the government needs to spend money, for example, to prevent another tragedy such as occurred in the small town of Walkerton, Ontario - where seven people died from drinking contaminated water and over 2000 became ill $^{5}$ - it must cut something else, say workplace safety inspections; if it wants to spend more on the homeless, it must cut culture or education. Worse yet, future Ontario governments with different views about public spending will be effectively denied the chance to reintroduce Keynesian policies of counter-cyclical public expenditure to stimulate the economy, to redistribute wealth through progressive taxation, to maintain or increase state-provided services, or to rebuild a public service with the energy and talent to conceive, design and administer welfare and regulatory strategies.

I want to stress that this is not a complaint about the fact that today's government happens to believe that the wisest policy is to lower taxes and deregulate the economy while yesterday's or tomorrow's government might prefer to increase state activities and expenditures and therefore to raise taxes. Such divergences are inevitable; they are of the essence in a democracy. My complaint is about the attempt by politicians of one persuasion to make it legally and practically impossible - to make it constitutionally impossible - for politicians of another persuasion to govern according to their view of what is necessary, right or feasible.

\section{CONSTITUTIONALIZING GLOBALIZATION}

Second, I want to point out that increasingly in today's globalized world, our constitution is being revised as much by international treaties and relationships as it is by domestic law and politics. Both the WTO and NAFT A constrain Canadian governments from embarking on various forms of activism - say regulation of consumer markets, the environment, competition or cultural industries. Chapter 11 of NAFTA, for example, allows foreign corporations to seek compensation from a private arbitrator if they are adversely affected by regulatory legislation enacted by a Canadian government. Several U.S. corporations have already received compensation — including lost future profits - for environmental and health regulations imposed by Canada; and not only have they succeeded in specific cases, they have intimidated Canadian governments into settling several claims prior to

See Ontario, Report of the Walkerion Inquiry: The Events of May 2000) and Related Issue (Toronto: Queen's Printer for Ontario, 2002). 
arbitration, and into abandoning controversial legislative projects. To restate the issue in formal, constitutional terms, NAFTA has introduced into Canadian jurisprudence a more virulent form of the American "takings" doctrine than prevails in its country of origin - though it benefits only foreign firms, not Canadian firms.

Other international developments also affect the legislative competence of Canada's Parliament. Our commitment to harmonize our intellectual property laws with those of our trading partners, especially the United States, forced us to repeal legislation which allowed us to produce cheap generic drugs. We may find ourselves unable to prevent the export of water or electrical power or the import of foreign cultural products and banking services because that would constitute discrimination against foreign firms. Our public health scheme might even be struck down as an illicit export subsidy or — if selected services are privatized - opened up more generally to foreign competition. Nor is the constitutional effect of globalization restricted to treaties like NAFTA . I want to briefly mention three other developments which have underscored the extent to which globalization - and continental economic integration - have altered our "real," if not our juridical, constitution.

The first is the process of what I call "globalization of the mind." "Right thinking people" in Canada and around the world, especially members of influential policy elites such as politicians, civil servants, academics and media people, have come to accept the premises of neo-liberalism as axiomatic, as needing no justification or explanation. The ideas that governments should be smaller, taxes lower, markets freer and states more open to trade and investment may not be quite as deeply ingrained amongst Canadian elites as amongst Americans. But it is a long time since these beliefs were challenged by anyone in public life who hoped to be taken seriously. They have become as much a part of our unwritten constitution as, say, the former belief that we have an obligation to share a little of our wealth with our fellow citizens so we can all enjoy reasonably equitable access to public goods and services.

Second, these beliefs became the guiding principles of our public policy not simply because they were espoused by influential and powerful Canadians, but because they were also held by bond dealers, currency traders and major investors in London, New York and Tokyo. If these people deem our welfare state too generous or our regulatory policies too aggressive, our dollar may decline even further, our stock markets may be trashed, our economy vandalized, our tax revenues diminished and our prosperity laid waste. I said these things "may" happen; but they may not. It doesn't really matter. What does matter is that governments are sensibly reluctant to find out. The stakes are just too high. So we now have a new analytic, a new set of values, a new constituency of interest - the global economy - with power to trump almost every other consideration in public policy debates. Whether we are talking about ind ustrial policy, tax levels, public infrastructure or culture, we cannot ignore the reaction, or anticipated reaction, of global markets. In effect, globalization has made marketfriendly policies a first principle of our constitution, which politicians violate at their peril.

And third, we have experienced a "hollowing out" of corporate Canada. Not only are many sectors of our economy dominated by foreign-owned multinationals; those same multinationals have been increasingly depriving their Canadian subsidiaries of autonomy, and transferring many of their key functions from regional head offices in Toronto or Calgary to global head offices in New York or Chicago. Nor are Canadianowned firms immune from this trend. As more and more of them are bought up by foreign-based corporations, their local executive cadres are dismantled or reduced in authority. As a result, leading elements of the Canadian business community are disappearing or shrinking, thus endangering key groups connected to them on the food chain - law firms, consulting firms, advertising agencies, real estate companies, software designers, and all the people from whom they in turn buy goods and services or whom they support with their tax dollars and charitable contributions - like universities for example.

How does this affect our Constitution? Canada depends on a strong civil society, on strong business leadership, strong financial institutions, strong knowledge-based industries, strong professions, strong urban centres, strong charities and universities supported by private donations as well as public funds - all of which are put at risk by this process of hollowing out. In this way, the real constitution, the operational constitution, adapts to the changing reality brought on by globalization and continental integration.

My point is not to deny the inevitability - let me say even the great benefit - of Canada joining NAFTA or the WTO or of importing American capital, ideas and ideologies. I simply want to point out that these developments have brought about a root-and-branch transformation of Canada's political economy. That transformation - which has been going on for a long time - intensified from about 1980 to 1990 , the very period when we were repatriating the Constitution, adopting the Charter and attempting to rewrite the terms of our federation at Meech Lake and Charlottetown. Like the changes in our formal 
Constitution, the transformation accomplished by globalization involved legal changes - repeal of the old legal regimes which had regulated international trade and capital flows, and their replacement by new, liberalized arrangements. However, the new legal framework of the global economy was hammered out in international forums where governments more powerful than our own set the agenda and shaped the outcomes. Thus, although globalization changed our Constitution even more profoundly than anything we did to the Constitution Act, 1982, there were no federal-provincial negotiations, no public consultations, no referenda, no Supreme Court references. Once we decided to accede to the new global legal order, all that remained was for parliament to pass laws implementing these treaties and to repeal legislation which did not conform to them. But make no mistake: the transformations wrought by globalization were pervasive and seemingly permanent. They were in a profound sense "constitutional."

\section{CONSTITUTIONALIZING POPULISM}

Canada has been experiencing a change in the discourse and deep structures of its political system. Populist movements - mostly of the right but occasionally of the left - have mobilized support for direct democracy which, they believe, would translate "the will of the people" promptly and without distortion into binding public policy. Consequently, they have disparaged representative governments, denied the legitimacy of both the courts and the executive, denigrated the views of professionals and public intellectuals, devalued the concept of public service, made the term "politician" a pejorative and in all these ways, removed activist government from our lexicon of plausible political choices. Ontario, for example, enacted its "Fewer Politicians Act" to great acclaim although, when combined with other legislation, its effect was first to shift power from local governments to the province, then to dilute access by citizens to their now-fewer provincial and municipal representatives, and finally to inscribe in legislative language the notion that reducing the number of "politicians" was comparable to the reducing the population of pests or predators. Simultaneously, Ontario dismantled public consultative bodies which were thought to be dominated by "special interests" such as women, labour and visible minorities and closed down "ivory-tower" agencies such as the Law Reform Commission. Finally, populists in and out of government right across the country favour referenda and recall elections to keep elected representatives on a short leash; they favour electoral laws which ensure a greater role for single- issue organizations in the political process; they favour constitutional amendments which permanently privilege rural voters and discount the power of metropolitan voters. In all this, populists have been aided and abetted — not to say incited - by powerful financial interests, rapidly consolidating media empires, and influential local elites, as well as by people of principle who are genuinely concerned about the alienation of ordinary citizens from the theory and practice of parliamentary government.

Ironically, populist mistrust of governments has been acknowledged and legitimized by both the courts and the legislature. Judicial decisions have overturned government action, held governments liable in damages for neglect or wrongdoing in the discharge of their functions, and imposed new procedural requirements on government agencies. And legislators at both the provincial and federal levels have proffered hostages to fortune in the form of new laws, policies and practices designed to create the appearance, if not the reality, of greater government accountability, transparency and responsiveness.

In short, we are gradually internalizing and institutionalizing, and thus constitutionalizing, populist attitudes and values. This may be a good thing or a bad one. But it is clear that the success of populism will reduce the influence of sophisticated ideas and expert analysis on policy formation, will undermine the parliamentary party system which advocates and propagates activist public policies, will deflate the willingness and capacity of ministers and members to rally support for such policies, and will diminish respect for the public service whose professionalism once earned it considerable trust. In other words, though perhaps an unintended consequence, to the extent that populism succeeds, it will construct constitutional barriers to the activist state.

All of this may be sweet music to people who believe that activist government deserves its fate, that it has left us legacies of debt and dependency which did considerable harm to Canada and Canadians. Maybe so, maybe not. My concern is that sometime in the future we may want more from the state than we think we want now. But we will not be able to get more. If populism becomes the way we think about government and politics, if populist ideas are entrenched in laws and institutions, if populist values are constitutionalized, we would not have the kind of state that can deliver what may someday be expected of it.

Representation Act, 1996, S.O. 1996, c. 28. 


\section{CONSTITUTIONALIZING A WEAK CENTRAL GOVERnMENT}

Fourth, there are strong decentralizing tendencies at work in the Canadian federation. A visitor from Mars or Moscow or east-end Montreal might think that the Constitution Acts give ultimate power to the federal government, but in practice things have turned out quite differently. The federal government's residual power over peace order and good government, like its jurisdiction over foreign affairs, trade, commerce and interprovincial undertakings, was emasculated early on by the conservative judges of the Privy Council. As a result, the federal government was unable to protect workers' rights, consumer interests or the environment. During the two world wars, and for some time after 1945, the federal government was able to use its powers to tax and spend in order to entice or coerce the provinces into cooperating in national social welfare schemes, public enterprises and regulatory programs. However, over the past twenty years, federal power has again shrivelled. Fear of secession has made the federal government wary of challenging Quebec's expansive use of its powers in the areas of education, immigration and foreign relations; other provincial governments refuse to collaborate in national strategies - such as implementation of the Kyoto Accord - which they deem to be hostile to their own interests; regionallybased populist parties ridicule Ottawa as remote and unresponsive; and the populist tax revolt has forced the federal government to reduce or abandon the shared cost programs which gave it the financial leverage with which to shape national social policies and economic strategies.

But the federal government is the only government that could conceivably stand up for Canada's interests as the nations of the world negotiate the rules of the global economy. It alone has any prospect of regulating transnational corporations and capital flows. It alone might be able to orchestrate the development of Canada's human, natural and capital resources to create the strongest possible economy. And it alone could animate social or cultural policies which would bind Canadians together. However, the federal government lacks the legal power, political will or financial clout to really do any of these things. As a consequence of this power vacuum at the centre of our federation, there is essentially no Canadian government today which can manage the issues thrown up by neo-liberalism and free trade, much less take us in a different direction if we decide that is where we want to go. In this sense decentralization is helping to cast in stone - to constitutionalize - a number of neo-liberal policies whose shelf life might expire some time within the next election or two.

\section{CONSTITUTIONALIZING JUDICIAL POWER AND INFLUENCE}

Fifth, a word about the juridification of our public life. From the inception of our federation, courts refereed disputes between the national and provincial governments, often favouring the provinces. From at least the 1920s and 1930 s, right down to the 1970 s, our judiciary was active - perhaps hyper-active - in reviewing administrative action, generally favouring individuals and corporations, rather than the state, unions or the environment. To say the least, these decisions were not regarded as brilliant by most academic experts and many political observers. But this judicial activism did not matter too much: determined governments found ways around court rulings, and generally got on with their programs. In 1982, however, we adopted a constitutional Charter of Rights and Freedoms which had several important effects.

First, it tempted marginalised groups such as women, aboriginal peoples and the disabled to seek magical, rights-based solutions, and thereby diverted their scarce resources and energies into litigation strategies and out of direct social action and progressive coalition politics. Alas, they gained little as a result. Judges, it turns out, cannot reconstruct cultures, reallocate public resources or pry the hands of rich people off the levers of power. Second, the Charter to some extent diverted public expenditure from social programs to legal services, institutions and processes, and prompted a shift from informal to adversarial procedures in many contexts. This has been a boon for lawyers, but costly for public bureaucracies, civil society actors and relationships between them. And third, the Charter has converted corporations into empowered citizens, who can finance endless litigation thus enabling them to dominate the electoral process, poison people with tobacco and frustrate whatever regulatory impulses still survive in government. This new juridified paradigm of social relations and politics in Canada has also weakened the activist state and strengthened neo-liberalism.

To sum up, but not quite to conclude: Canada's constitution is changing quite dramatically. However, except for the Charter, it has not been formally amended. The changes have resulted primarily from treaties, legislation, and judicial interventions, and especially from the restructuring of our economy, and the reconfiguration of our political discourse, processes and culture. Under this latest version of our constitution, the Canadian state is no longer active but passive, no longer powerful but weak, no longer centralized but devolved, no longer responsive to domestic policy preferences but to global market forces 
and ideologies, no longer governed by parliamentary politics and the civil service but increasingly by populist impulses and legal proceedings. These new attributes of the Canadian state are said to be essential for our national interest and uniquely congenial to our national character. That is why they are "constitutional": they have become normative bedrock; they are long-lasting, they find their way into legislation and judicial interpretations; they become embedded in invented traditions and imagined conventions; they fundamentally shape the way we think about things as lawyers and citizens; and they are as difficult to change as any provision of the Constitution $\mathrm{Act}^{7}$ itself.

Whether as a cause or a consequence of juridification, lawyers and judges are starting to talk differently about the constitution than they used to. In particular, we are hearing a lot these days about the "unwritten constitution." Counsel have argued, and judges have agreed in cases like the Patriation Reference $^{8}$ and the Secession Reference," that "the unwritten constitution" allows courts to make authoritative - but not legally binding pronouncements about highly controversial political issues. The Supreme Court addressed these issues not, for the most part, by applying the law of the constitution, but by "finding" long-lost constitutional practices or conventions, rewriting Canadian and British history, proclaiming a consensus about the rule of law, democracy and pluralism, piggy-backing on international law and custom, and responding to the felt necessities of our time. Likewise, in interpreting the written constitution, the Court in cases like $\operatorname{Egan}^{10}$ and Vriend $^{11}$ used some unusual techniques - notably, extending Charter protection to groups "analogous" to those named - to make a different kind of political decision. I applaud the outcome of all these cases. But I disagree strongly with the Court's methodology because it opens the door to more juridification, more frequent and sweeping challenges to parliamentary politics, and more intrusive review by judges of executive action on the basis of ideology disguised as history, self-evident truth or fundamental principle.

Is it possible to mount a legal challenge to juridification on the grounds that courts are exceeding their mandate and making political decisions for which they have no special competence or authority? Such a challenge is unlikely to be successful. Courts have a

Constitution Act, 1982 , ss. 38-49, being Schedule B to the Canada Acl 1982 (U.K.), c. 11

8 Reference re Resolution to Amend the Constitution, [1981]1 S.C.R. 753

Reference re Secession of Quebec, [1998] 2 S.C.R. 217

10 [1995] 2 S.C.R. 513

11 [1998] 1 S.C.R. 493 way of pulling themselves up by their jurisdictional bootstraps Ask a judge, for example, where courts get the power to issue labour injunctions or to review the decisions of administrative tribunals. "Simple," the judge will say: "we have inherent jurisdiction." This is something of a conversation stopper since there is no way to challenge that statement, except by appealing to another judge who will tell you the same thing. This does make things a bit awkward sometimes, as when courts tell us that the exercise of inherent jurisdiction can neither be precluded by Parliament ${ }^{12}$ nor held to Charter standards. ${ }^{13}$ But let that pass. Let pass too the somewhat unseemly spectacle of judges claiming that as the human embodiment of "the rule of law" they have the right to prescribe the procedures for setting their own salaries ${ }^{14}$ or — on their own motion - to hold in contempt people lawfully picketing their courthouse. ${ }^{15}$ The point I want to make is that concepts such as "inherent jurisdiction" or "unwritten constitution" hint that like myself, judges may be - to some extent and with great respect - constitutional donkeys. They too are not quite certain what the constitution is, and they too conceal their uncertainty in vague, emotive language which enables them to reach political conclusions.

However, I do not want to be too hard on judges. After all, some clever lawyer made them do it. But I do want to be a bit hard, just for a moment, on the cleverest, the most loveable, lawyers of them all those who teach in law schools. They too - we tooare guilty of some serious heresies which have helped to shape Canada's new constitution. Until fairly recently, they - we - accepted that law was made by the legislature, interpreted by the courts and enforced by the executive. Lately, however, we have been revising our map of the legal system. My own heresy is called "legal pluralism," a socio-legal theory which holds that the state has no monopoly on law-making, that law emerges from all social and economic contexts - from universities, workplaces, families and business networks. Another, somewhat similar heresy, is embraced by law professors who advocate a new constitutional status for first nations and a recognition of their traditional rights and legal processes. A third, with quite different roots, is the law and economics movement, which argues that markets generate their own legal and political logic. These are quite different theories, but they have this in common: all of them envisage systems of law which do not originate in or

\footnotetext{
Crevier v. Quebec (A. G.), [1981]2 S.C.R. 220

R.W.D.S.U. v. Dolphin Delivery, [1986] 2 S.C.R. 573

Reference re Remuneration of Judges of the Provincial Court, [1997] 3 S.C.R. 3

15 British Columbia Government Employees' Union v. British Colu mbia, [1988] 2 S.C.R. 214.
} 
derive from the Canadian state. In that sense, they are all pretty radical constitutional heresies.

Of course, you might say that law without the state is a typical academic flight of fancy, and does not deserve further consideration. Would that it were so. But life these days has an odd way of imitating art, and we are in fact making great strides in detaching law from the state Today there are more private police in Canada than public police; prisons are being privatized; voluntary corporate codes of conduct are replacing statutes; public enforcement of environmental and labour standards is giving way to self-regulation or being contracted out to the private sector; arbitration and other forms of private dispute resolution account for a growing share of litigious business. In other words, legislation, public security, law enforcement and the administration of justice - the original and, as we once imagined, the core functions of the state - are no longer constitutionally sacrosanct.

All of this, I want to say, has potentially huge implications for a lawyer's understanding of the constitution. What is law, and what is the rule of law, now that the state no longer claims a monopoly over making, administering and enforcing it? On what grounds might a court claim jurisdiction over, say, discipline in a private prison? What liability does government have for the acts or omissions of private agents which have assumed its previous functions? Our legal vocabulary, I think, is starting to adjust to this new constitutional reality. For example, we seem to be using the word "governance" more and more, and the word "government" less and less. "Government," we might say, is the process by which states exercise the power they are given by their constitutions. By contrast "governance" is a more generic process which encompasses the ways in which private as well as public organizations direct their affairs: hence "university governance" or "corporate governance" or "governance of the global economy." We use the word governance in order to focus on how things get done, with no special importance being attached to who or what is doing them. Like conceptions of law without the state, "governance" conjures up a new constitutional order in which the state is no longer regarded as the ultimate source of power and legitimacy in our society, in which government is no longer the indispensable instrument of our collective ambitions and the guarantor of social justice. In such a constitutional order, it follows that government is merely one supplier amongst many of public goods and public services, and that its performance must be judged by the same bottom line standards as competing providers such as corporations or markets.
This new constitutional order has not escaped the notice of lawyers who are suing governments more often and more successfully for acts or omissions that were once considered acts of state or political questions beyond the purview of the courts. Such litigation, in turn, changes public perceptions and expectations of the state, and reinforces underlying disaffection with the state. As a law professor, I know that it is easy to overestimate the capacity of myself, my colleagues, my students and the few readers of my articles to rewrite the constitution. And in this case, frankly, I would be happy to learn that I made no contribution whatsoever. Nonetheless, I do mutter the odd mea culpa now and again.

\section{CONCLUSION: THE DONKEY'S PERspective ReVISITED}

I have argued that neo-liberalism, globalization, populism, decentralization and juridification are transforming Canada's political economy, and reshaping its constitution. But I must confess that I have neither asked nor answered what is arguably the most important question of all: what does it really mean to say that our constitution has been reshaped, that some new constitutional assumption, value or process has been chiselled in stone? If I had to answer that question, to be honest, I am not sure how I would. Remember: I am a constitutional donkey. I do not know whether constitutions are a cause or an effect of fundamental change, or neither of the above. I do not know whether we think their provisions are chiselled in normative bedrock because constitutions actually do make the state the way it is - or whether they are just categorical statements about how we want things to be or believe them to be. On the contrary - I sometimes ask myself - is it possible that constitutions in the full, extended sense of the term are in fact not so fundamental or long lasting after all, that they are always being re-imagined, always being rewritten? To a donkey like me, this last is a very intriguing prospect.

\section{Harry W. Arthurs \\ Professor of Law and Political Science, and President Emeritus, York University, Toronto.}

Versions of this text were originally presented as the Mervin Leitch, Q.C. Lectures at the Universities of Alberta and Calgary on 30 January and 1 February 2002, respectively, and at an interdisciplinary colloquium at the University of Sydney, Australia, on 17 March 2002. I am most grateful for the invitations from the three host institutions, and for comments received by participants at these three events, especially those of the editor of Constitutional Forum, Tsvi Kahana. 